\title{
Reasserting work, space and gender boundaries at the end of the Second World War
}

\begin{abstract}
When you come out of the Forces you will have eight weeks' leave in which to look round and take stock of your position ... You have seen much, and you will bring to civilian life a broadened outlook. It may be that during your period of service you concentrated on one special branch of nursing work, while possibly losing touch with developments in other fields. Perhaps you held posts of great responsibility ... While you have been away, those at home have had to carry on as best they could with sadly depleted ranks; so of one thing you can be certain: the civilian nursing service desperately needs your help ... The vacancies are many, and if you have qualities of leadership, the big posts at home will be yours in the end; but do not be disappointed if, because you have held a position of authority in the field, you do not step straight away into a similar position at home. Not everyone who has risen to a matron-ship in His Majesty's Forces can hope for an immediate matron's post at home. ${ }^{1}$
\end{abstract}

These words, the RCN hoped, would galvanise demobilised military nurses to return to hospital practice. Its focus on what they could expect appears to have had the opposite effect. Many QAs had indeed worked in specialist areas, but within their work they had developed innovative practices, learnt new ways of working and established a more human-centred approach to patient care. The lack of understanding of these critical professional attributes would alienate the returning nurses and ultimately deny their talents to the British hospital service.

The vast majority of nurses whose stories have been used in Negotiating Nursing married and left the nursing profession, although some returned later in life when their children had grown up. A few went abroad to nurse, and at least two died young. The only testimony to identify both a satisfying professional career and a long and happy 
married life is that of Sister Catherine Hutchinson. Previous histories of allied military nurses have argued that they did not wish to return to hospital nursing because of its petty restrictions. ${ }^{2}$ None of the testimonies in this book articulates this specifically. However, the evidence that is available suggests that hospital nursing was not a popular post-war choice.

The chapter considers the civilian world into which the QAs returned at the end of the war and explores the options they faced. It begins with the immediate aftermath of war and the opportunities for interesting and worthwhile work that would only exacerbate the nursing sisters' difficulties on demobilisation. This is followed by a consideration of the return to Britain and the options open for professional practice. It will be demonstrated that some nurses opted to return overseas, some entered work tangential to the nursing profession and some made careers in public health. A few remained in the military. The chapter then focuses on what was the main professional option for returning sisters - the crisis-ridden civilian hospital system. However, as it is argued, there were several constraints that made this unattractive. The nursing profession itself displayed a lack appreciation for the nurses' talents. Hospitals continued to demand complete devotion to the institution and its patients from female nursing staff, with the attendant need for nurses to live in. ${ }^{3}$ Many nurses had married on active service overseas, or planned to marry at war's end. Unlike the social expectations of the men who became their husbands, for women, marriage was not expected to be combined with work outside the home, and this was only partly because of the professional boundaries placed on them. The reassertion of traditional gender rules post-war re-established discomfort with married women's work, ${ }^{4}$ although in reality this never fell to pre-war figures. ${ }^{5}$ It was considered highly desirable that marriage would rapidly lead to children. ${ }^{6}$ Across the globe, the division of domestic labour was heavily focused on the wife, ostensibly compelling women to return to the home and remain there. ${ }^{7}$ Finally, therefore, the chapter explores the choice of the majority: marriage, family and domesticity. 


\section{'An air of uncertainty'}

The bombs fell on Nagasaki and Hiroshima, August 15th 1945 became V.J. day and there were reverberations around the world. Reverberations were also felt at the 139 British General Hospital, Ranchi, Binar, India, where I was one of a contingent of Army nurses (QARANC) looking after the wounded from Burma. Excitement about the end of the war was followed by panic as an air of uncertainty prevailed. ${ }^{8}$

Anxieties about the end of the war resound through many of the nurses' testimonies. Sister Catherine Butland reflected on it being 'regretful that the seven months just past could not go in indefinitely, though very glad the fighting was over'. ${ }^{9}$ However, for many nurses the war did not end in 1945, but as late as 1947. In the latter months and immediate post-war period, the needs of POWs, civilian inmates in concentration camps and the millions of starving people across the globe were to concentrate the minds and skills of some nursing sisters and provide further valuable work. In August 1946 Sister Ann Radloff was posted to a hospital train in Palestine. As she had been in the Army for over two years, she was designated 'Officer Commanding Train'. Although she admits that she had never 'felt less in command of anything' and that 'no-one took me seriously', her position, even nominally being in charge of anything but a hospital ward, contravened normal professional and gender rules and would have made Radloff's return to pre-war hierarchies challenging. ${ }^{10}$ She was demobilised in 1947 after 'three years of exciting, terrifying and varying experiences. I look back in gratitude for the friendship and camaraderie of which I was part.'11 Radloff was not to return to England permanently and later lived in South Africa, India and Nepal. ${ }^{12}$

Not all overseas postings were so savoured, especially those with the British Army of the Rhine (BAOR), although it is not clear if this is because of the work or the depressing nature of post-war Germany. ${ }^{13}$ On 7 June 1945, Sister Mary Morris wrote in her diary: 'I have received my demobilisation number today, 56, whatever that means. I signed for the duration of the war, but in the medical corps that really means the duration of the emergency which is a different matter. ${ }^{14}$ There was no immediacy reflected in her demobilisation orders and in 1946 she was posted to Munster. Sister Elsie Gordon, 
also with the BAOR, wrote to the Nursing Times from post-war Berlin: 'the outlook is desolate and the atmosphere in Berlin very depressing. The sisters are glad of fairly frequent periods of leave. ${ }^{\prime 15}$ Morris herself maintained that her original posting to Munster with the 25th British General Hospital was the "dead end" of B.A.O.R.'. ${ }^{16}$ Following her marriage in October 1946, she was posted to Hamburg, where at least she and her new husband could be in the same city. ${ }^{17}$ She was eventually demobilised in July 1947. Her diary entry for 27 July of that year reads, 'Today I am a civilian. It is so wonderful to be away from nursing and hospitals. ${ }^{18}$

As the war in Europe drew to a close, the focus was switched to the continued hostilities in South-East Asia. Many sisters were sent to India to care for those men released from Changi and other Japanese camps. ${ }^{19}$ One anonymous sister recalled that she was nursing men whom she had previously nursed in Italy; for some it had been a very long war. ${ }^{20}$ Sister C.M.S. Baker's final posting in September 1945 was to care for released British POWs:

We had to cope with men, after years of deprivation, cut off from news of family and home, suffering from malnutrition and the effects of cruelty, who now had to adjust to a normal way of living. Some hid their food in their lockers ... in case ... [ellipses in the original] some wept uncontrollably at times and some wanted to stand to attention if spoken to ... We let the patients do their own thing ... We had no routine, treated them as gently as possible and accepted some eccentricities. ${ }^{21}$

Other nurses were posted to care for the liberated civilian inmates of Nazi concentration camps. It is the experiences of nurses who were part of the liberation and later rehabilitation of the inmates at Bergen-Belsen concentration camp that provide some of the most traumatic narratives of early post-war nursing work and illustrate the impending difficulties that these nurses would have on return to Britain. ${ }^{22}$ Sister Mary Bond was posted with 29th British General Hospital to Belsen in May 1945, by which time 'I was proud to be a senior Sister with many added responsibilities'. ${ }^{23}$ Bond was placed in charge of one of the hospital blocks at the camp, but she 'felt inadequate in [her] capacity as a nurse to even try to counteract in any way the atrocities they had suffered'. ${ }^{24}$ Key to her ability to support those in her care were her fundamental nursing skills that she had learnt 
in her training, combined with the shifts in work and nurse-patient relationship boundaries developed in the war:

Also under my supervision in Square Eleven was a ward full of patients suffering from Cancrum Oris - extensive ulceration of the mucus lining of the cheeks due to lack of mastication and malnutrition. The patients developed holes in their cheeks, and the tongue could be seen moving as they spoke. Even though I had learnt of this condition in nurse training, this was the first time I had ever encountered it when practicing. Such was the lack of control over the mouth area that feeding was made very difficult. After each feed we had to wash the mouth, cleanse the surrounding ulcerated areas, and spray them with penicillin. ${ }^{25}$

Sisters Myrtle Beardwell and Molly Silva Jones of the British Red Cross were amongst the first nurses to enter the camp in April 1945, joining Lieutenant Colonel Johnston, RAMC with 32 CCS. Silva Jones described how the patients' cries for food, "will haunt the ears of those who heard them for a long time to come'. ${ }^{26}$ She was 'Stirred [with] an increased desire to help; nothing we could do was enough to attempt to restore these sub-humans to some measure of mental and physical health. ${ }^{27}$ In a letter to the Nursing Times Sister B.B., with the 2nd Army, wrote, 'Soon we shall be leaving Belsen, with no sorrow and no regrets. We shall remember it only as a sad, harrowing experience. ${ }^{28}$

Despite the nurses' doubts of their abilities to help the survivors, they were considered by the senior medical staff to be the most critical members of the team. Lieutenant Colonel F.M. Lipscombe, RAMC, also with 32 CCS, maintained that 'Better results might have been obtained with a larger staff of skilled nurses. ${ }^{29}$ Johnston even admitted in one report that 'medical skill is of secondary importance' and that the most important resource requirement was nurses. ${ }^{30}$ Nursing staff were integral to the work at Belsen as they eased the suffering and, alongside relief workers of all nationalities, worked to restore life and humanity into the camp's survivors. ${ }^{31}$ The importance of the nurses' work rendered their skills essential to the liberation of the inmates and created a collegiality with their male colleagues that perhaps even surpassed previous war work. ${ }^{32}$ Other nurses found that they were now not only the colleagues of the medical profession, but their leaders.

Barbara Mortimer cites the letter home by Sister Mary Copeland in which she described how she was 'now running a building with 180 
patients who are being looked after by ten German orderlies, three German sisters and two German doctors, and I might add it is not an unpleasant position to be in, that of supervising doctors, and telling them what to do, quite apart from them being Germans' ${ }^{33}$ This reversal of professional order was also described by Sister Mary Sands, a QA who arrived, probably with 32 CCS, soon after the liberation. ${ }^{34}$ The nursing sisters had significant autonomy in their duties. Sister Kathleen Elvidge wrote home: 'There is one English doctor to each square of five blocks, so as you can imagine we don't see much of her. Then we have some Belgian medical students who also help, I've got two assigned to my block.' 35 The official sanctioning of male doctors and medical students being placed under female nurses was a considerable alteration of normal gender and professional rules. For these nursing sisters and others from across all war zones, the multiple ways and situations in which they had been placed in authority, given autonomy and had developed new ways of working would be lost in the return to peace and pre-war hospital hierarchies. For some nurses the end of the war offered an extension of interesting, if harrowing work, but there was a growing 'normality' that was felt by some even as they returned to Britain's military hospitals.

\section{Return to normality?}

Sister Penny Salter's reaction to her return home from active service overseas was one of boredom and a lack of commonality with those who had stayed behind:

Arriving back in the United Kingdom was quite an anti-climax, and I found on meeting my parents and relatives again I was quite lost, as if we had nothing in common anymore. Also I was not interested in anything or anyone pertaining to the family, as for Christmas in the immediate future, that was the last thing I wanted, everyone going out of their way to please me made me feel worse than ever, all I wanted was to get away and be myself ... However, one morning in Piccadilly Circus, outside the well-known store of Swan and Edgars, who should I bump into but my surgeon friend Colonel Van Rensburg and his wife from Kenya - It was quite extraordinary for amongs't [sic] our conversation on mentioning my feelings he soon assured me by saying this was quite a normal reaction, many people felt the same - not to worry, it would soon wear off. I wondered ${ }^{36}$ 
Like many returning Army nursing reservists, Salter had a period of demobilisation leave, after which she states, 'it was quite a relief when I eventually received my posting orders to report to the Military Hospital at Stover Park in Devon'. ${ }^{37}$ Too soon she realised that military nursing in a British hospital was not as interesting as an overseas posting: 'The work itself I found most boring, mainly because it was so dull, including medical boards and the chronic sick from Burma. ${ }^{\text {'38 }}$ The boredom did not abate, and on 1 May 1947, Salter left England to join the Medical and Nursing Service of Rhodesia (now Zimbabwe). ${ }^{39}$ During the war, nursing sisters of the British Army had been posted to hostile zones in which the hospitals were 'filled to the brim with unceasing casualties, terrible wounds and shocking conditions' ${ }^{40}$ It was no surprise that they struggled to find satisfaction in positions and work that echoed pre-war professional life. ${ }^{41}$ Overseas service had been an adventure and a heroic endeavour; nursing back in Britain was mundane and firmly relocated within the gendered and professional expectations of the female nurse and women more generally. ${ }^{42}$

Sister Jessie Wilson was sent home in 1943 after several periods of ill health. Following her recuperation, she managed to organise a posting to work at a hospital in the Midlands with her old matron from the Middle East. Excited about seeing her again and reminiscing, her memoir demonstrates the frustration of many of the returning nurses when she wrote: 'Matron told me things were very different from the way things were run in the Middle East and one had to readjust one's ideas. ${ }^{43}$ Sister P.M. Dyer returned to Britain to be posted to Aldershot Military Hospital in Surrey:

Those first few weeks back in civilised surroundings were like commencing training days all over again. The greatest tragedy of all appeared to be that everyone, bound up in their efficiency, had become quite mechanised and the art of a sense of humour seemed to have disappeared ... the greatest hardship was to be told by a senior Sister how to carry out a particular job and with complete demureness one answer [sic] 'Yes Sister', 'No Sister', 'Certainly Sister'. ${ }^{44}$

It was clear to those nursing sisters who had experienced overseas service that their colleagues who had remained in Britain had little idea of the lives they had led during the war. The RCN recommended 
its demobbed members to be realistic about their talents and abilities to work in civilian hospitals. ${ }^{45}$ In reality, it was their colleagues on the home front who had been 'left behind' in the scientific and nursing developments that had occurred in the midst of battle. ${ }^{46}$ In May 1945, the British Journal of Nursing had published a statement from Major-General Norman T. Kirk, the Surgeon-General of the US Army. In it he maintained that 'the Army Nurse is living five years ahead of the Nursing Profession. She is handling new drugs, applying new treatments and working with the surgeons who are making history in medical circles during this war. She is gaining experience years ahead of her civilian opportunities. The urgent need for nurses continues to be critical. ${ }^{37}$ Notwithstanding such sentiments, military nurses returned to British hospitals where they were expected to follow nursing regimes they had abandoned on active service. Even military hospitals in Britain would not countenance the continued autonomous ways of practice of those who had experienced overseas postings. The stifling of returning military nurses' ingenuity and abilities to improvise was a forerunner to the realities of civilian practice. Some nurses could not and would not accept these options. For a fortunate few, the chance to remain in the military, or join the Colonial Office and return to overseas service, meant that they could pursue the autonomy of practice they had so relished during the war.

\section{Returning abroad}

At the end of the war, the 12,000-strong QA force was reduced to its 624 peacetime numbers. ${ }^{48}$ Those who had joined as regulars before 1938 could remain in the service, but the reservists were demobilised. Sister Vera Jones wrote to her parents from India on 29 December 1944, informing them that she had applied to join the regulars of the QAs, with the full support of her principal matron. ${ }^{49}$ Less than one quarter of the 455 nurses who applied to join as a regular at the end of the war could be accepted. ${ }^{50}$ For those who were recruited or retained in the service, the opportunities of overseas postings and the professional status afforded by commissioned officer rank were highly attractive and some women had important military nursing careers. Sister Monica Johnson, later Dame Monica Golding, had served with the BEF and then in Egypt during the war, and was posted 
to India as Principal Matron between 1946 and 1948. She became Director of Army Nursing Services of the QARANC in the early 1950s. ${ }^{51}$ Sister Margot Turner, later Dame Margot Turner, became Director of Army Nursing Services of QARANC in $1964 .{ }^{52}$ Turner had been posted to Malaya as the Japanese invaded in December 1941 and spent the rest of the war in Japanese internment camps. ${ }^{53}$ Despite this, on her release in October 1945, she wanted to return to work and within 18 months was on active service again. ${ }^{54}$ Nevertheless, given the quota of the peacetime nursing service, the prospect of such an interesting professional life was limited to only a very few.

There was also the option to join the TANS, and several nursing sisters did so, though little is known about their post-war lives. ${ }^{55} \mathrm{~A}$ few Second World War nurses were lucky enough to combine both public health work and travel abroad, although the evidence is sparse, and they appear to have been only a very small minority of the cohort. For example, G. Padfield, who had been a reservist, found a post-war career as a health visitor for the Libyan government. ${ }^{56}$ Sally Hepworth joined the Foreign and Commonwealth Office and was posted to Malaya. ${ }^{57}$ Sister Marjorie Hunt admitted that she 'couldn't settle down after the war' and went to Rhodesia in 1946 following an interview with the Society for Professional and Business Women. ${ }^{58}$ Others secured work in careers tangential to nursing. Jane Patterson, who had been Chief Principal Matron in India until 1947, took up a post as the Warden of the International House for Students, the residence for those nurses from abroad studying post-registration courses in London. ${ }^{59}$ Such opportunities were limited, however, and with the vacancies for hospital nursing across the country in the thousands, demobbed military nurses were called upon to take up these posts.

\section{A professional future?}

The promised new welfare state needed more nurses, health visitors and social workers. ${ }^{60}$ The hospitals of the NHS founded on 5 July 1948 would need a skilled nursing workforce. ${ }^{61}$ Sister Catherine Hutchinson was demobbed in December 1946. When she was on demobilisation leave, she read an article in the Readers' Digest about the work at East Grinstead Hospital. Later, on seeing an advert in the Nursing Times for a year's course in 'Burns' nursing, plastic 
surgery and jaw injuries', she applied. ${ }^{62}$ On 14 June 2001, she wrote that 'Many of the war-time burnt air crew were still there, receiving treatment (McIndoe was still there doing his pioneering work). With them as a group, I fell in love, married one, worked in the hospital for 23 years and lived happily ever after. ${ }^{63}$ Sister Helen Luker also returned to hospital nursing. She was first appointed as the tutor for the preliminary training school of the Nightingale School of Nursing at St Thomas' Hospital, where she herself had trained. Later she went to St Thomas' country hospital, Hydestile, as Sister-in-Charge. Luker was still in post when, in May 1957, she suffered a seizure and died. ${ }^{64}$

Although Luker's career ended in her early death, both she and Hutchinson had secured work that would allow a level of autonomy reminiscent of their war careers. As is discussed in Chapter 3 of this volume, nurses were obliged to accept harassment and unwanted sexual advances at East Grinstead Hospital, but they were also given professional and clinical responsibilities that were unusual in hospital practice. It is significant that amongst all the nurses' testimonies, it is these two who identify their post-war careers, given that they both had the opportunity for professionally satisfying work within hospital nursing. Information regarding other nurses who, on return from active service, chose hospital nursing practice is very limited. Penny Starns identifies problems related to the recruitment and retention of nurses in general, which were, she argues, due to the arch-regimentation of hospital life in response to the increased militarisation of the nursing profession. ${ }^{65}$ Whilst this may have some credence, demobbed nursing sisters were used to the form-filling and rank-awareness of the military and are unlikely to have been particularly alarmed by this. Rather, as Barbara Mortimer maintains, it was 'the prospect of returning to nursing in a traditional, hierarchical hospital setting' rather than a new militarisation of hospitals that 'was not appealing. ${ }^{66}$

The nursing profession at home failed to appreciate the demobbed sisters' clinical knowledge and new methods of patient engagement. Military nurses had developed a knowledge base related to postoperative care, intensive care treatments and diagnostic awareness. They were used to practising with levels of autonomy that were not permitted and that in some cases were not even acknowledged in post-war hospitals. ${ }^{67}$ It was not unknown for ex-military nurses to 
get patients out of bed post-operatively, only for civilian nurses to put them back again. ${ }^{68}$ Such dissonant attitudes to nursing care frustrated the ex-military nurses and angered the civilian ones. As Starns argues, 'the war on the wards continued'. ${ }^{69}$ Civilian nurses expected their demobbed military nursing colleagues to return to civilian work and abide by its rules, just as they had done before the war. ${ }^{70}$

Sisters Catherine Butland and Vera Jones were both unsure of the opportunities for nursing sisters in the post-war period. Jones wrote to her parents on 30 September 1944 of her thoughts about joining the regular QAs after the war:

It will not be easy to find good positions in civil hospitals, for while we are away overseas, other nurses are being trained and they in their turn will seek trained nurse positions. The new Rushcliffe rates of pay will draw many more girls to nursing from now onwards and the hospitals should never again suffer that acute shortage of staff as during my training. ${ }^{71}$

Jones was wrong about staff shortages and the 'draw' of improved pay. ${ }^{72}$ The Rushcliffe Committee may have increased nurses' salaries, ${ }^{73}$ but the 40 per cent rise in the cost of living between 1940 and 1943 all but obliterated the improvements. Nurses were no better off. ${ }^{74}$ She was, however, right in her summation of the difficulties in finding good positions in hospitals. Butland was equally unsure of her future, believing that her skills as an Army nursing sister would not be useful in civilian practice, the two jobs being so different. Furthermore, she maintained that those who had stayed at home and those who had been demobilised early would get the most 'enviable vacancies', leaving those still on active service overseas with the least attractive jobs. ${ }^{75}$ Her prescience in this matter demonstrates an awareness of the difficulties that nurses returning from war would face - not because the skills they had developed would not be valuable to the new scientific management of patients, for example, in the provision of penicillin regimes, but because they were not wanted.

An editorial in the Nursing Times on 19 January 1946 offered this blunt assessment of demobbed nursing sisters: 'Even though they may be obviously abler women, many committees of management will not have the courage to appoint them. ${ }^{176}$ Butland's later comments suggest an acknowledgement of the difference in status between military and civilian nurses that would fuel intra-professional rivalry and jealousy. 
Butland's memoir ends with, 'Now I was no longer a member of the Q.A.I.M.N.S. but just a civilian nurse, and my thoughts were identical to what they were when I first received my calling up papers - I wonder what the future will hold?'77 The use of the word 'just' is intuitive. There is an almost fatalistic appreciation that, as a civilian nurse, her professional status would reduce and that the work would once again be mundane. Indeed, not only did hospitals struggle to recruit returning nurses, they struggled to recruit nurses at all.

According to Susan McGann and colleagues, in March 1945 there were 11,000 hospital nursing vacancies. ${ }^{78}$ Three years later, in 1948, the total shortfall was somewhere between 40,000 and $50,000 .{ }^{79}$ In December 1948, the British Journal of Nursing published highlights of a House of Lords debate on the nursing shortage. In the opinion of Lord Crook, it stated, the 'actual number of vacancies for nurses was 33,000 , though to meet the present-day shortage 50,000 nurses, and no less [sic], were required. The efficiency of the Health Service would depend upon the number of nurses obtained. ${ }^{80}$ In a letter to the editor of The Times on 16 May 1945, Gladys Carter and Evelyn Pearce wrote that 'The shortage of nurses causes concerns to Ministers and public alike and threatens to bring the hospital services to a full stop. ${ }^{\text {81 }}$

British hospitals were struggling not only to recruit returning military nurses, but also new students. The status of nurses in training, Carter argued, was dubious, and calling them students 'camouflaged' their uncertain position. This would, she maintained, continue to create difficulties in the aspiration to establish nursing as a desirable profession. ${ }^{82}$ Even Dame Katharine Jones thought that some of the criticisms in the press and media about the pettiness of hospital life were 'not without some justification'. ${ }^{83}$ References to nurses as workers, 'ancillary to medicine', did little to raise the profession's prestige and were even disliked by doctors. ${ }^{84}$ The profession's attempts to persuade young women to enter nursing with promises of its 'marvellous opportunities for service' may have been 'true enough and the argument is therefore powerful. But it has one blemish and it is fatal. It does not persuade those women it aims at persuading. ${ }^{85}$

If the health system as a whole needed the demobbed nurses to resume their nursing careers, hospitals themselves did little to encourage them. Most hospitals continued to advertise for nurses who would be required to 'live in' and identified the residential 
emoluments in support of this expectation. ${ }^{86}$ The Nursing Times ran a series of articles from 1945 on the matter of 'living in', but advice that non-residential posts should have been made available seem to have been ignored. On 11 August 1945, the editorial of the Nursing Times argued that the question of a non-resident staff nurse and ward sister was 'a vital matter or the future of the recruitment problem'. ${ }^{87}$ In December 1945, the Nursing Times was even calling for student nurses to be allowed to live away from the hospital..$^{88}$ In February 1946, the particular problem of the needs and wishes of demobbed nurses to live independent lives was raised, ${ }^{89}$ but there is nothing to suggest that any of these demands were met. The blame cannot be laid entirely at the door of the profession.

According to an editorial on 17 November 1945, Aneurin Bevan stated that 'all had accepted the principle that trained nursing staff should be readily permitted to live out ... Unfortunately the proposed increase in the living out allowance is not sufficient. ${ }^{50}$ Furthermore, whilst demobilised medical officers were provided with funded post-graduate training, the same options were not available to the demobbed nurses. ${ }^{91}$ Even the Nursing Times could see that such policies conspired to keep returning military nurses from hospital practice and would in turn stymie educational and professional advancements. ${ }^{92}$ Yet rather than addressing such inequities, the profession turned to women from overseas and the very young to staff the wards of the country.

Recruitment drives in former colonies to find women willing to train as nurses were established in the late 1940s, but many would be channelled into the lower-grade state enrolled nurse (SEN) training that had been created in the war years to alleviate nursing shortages. This move supported the class superiority of the registered nurse and created de facto racial segregation in the profession. Many of these nurses realised too late that the SEN qualification had no currency anywhere else in the world. ${ }^{93}$ Nurse training schools also developed 'Nurse Cadet' schemes to bring young girls into the sphere of the nursing workforce before they could find alternative work on leaving school $^{94}$ - a scheme that Penny Starns asserts was little more than child exploitation. ${ }^{95}$ The Ministry of Health did not agree to the return of compulsory educational entry criteria into nursing until 1959. ${ }^{96}$ The consequence of such a policy was that nurse training 
schools were free to recruit girls with only two 'O' Levels that could be taken serially. Thus, apart from in the prestigious teaching hospitals, nurse training programmes and, ultimately, the hospitals of Britain were replete with academically weak students. ${ }^{97}$

In order to recruit more experienced staff to the healthcare system, the profession then focused on those men who had been released from the forces. These former RAMC orderlies were offered shortened training without the requirement to live in, to try to arrest the growing numbers of vacancies in hospitals. ${ }^{98}$ Although these men, like female nurses recruited from the former colonies, were usually in the lower ranks of nursing, male nurses were paid a higher salary than their female counterparts. This understandably caused significant consternation, including within the RCN itself. ${ }^{99}$ Male nurses were therefore neither the cheaper option, like nurses from the former colonies and cadet nurses, nor were they likely to be as malleable. Nevertheless, despite the attractive conditions of service offered to ex-military orderlies, recruitment from their ranks was also limited. These strategies that failed to attract experienced nurses and favoured cheap and frequently less able candidates meant that in order to protect patients, ward sisters had to assert careful discipline. The authoritarian regime did not appeal to those nurses returning from overseas postings. Most simply married.

\section{'Your nursing days are over, sweetheart'}

After the chaos of the war, the nation wanted to return to stability and most women returned to the home, marriage and family. ${ }^{100}$ Although the marriage bar in nursing had been lifted during the war, it was all but re-established in its aftermath. ${ }^{101}$ That is not to say that it was impossible to combine the two, as the discussion of Catherine Hutchinson's post-war career above demonstrates. Nevertheless, despite the shortage of nurses, many hospitals created significant obstacles to the employment of those who were married. Most of the nurses whose testimonies have been used for this book married men they had met on active service, thus denying their skills to the British health system. Sister Florence Hardy joined the QAs during the Second Front and was posted to France, Belgium and Germany. She was demobbed soon after the end of the war and spent some 
time as a private nurse and then worked in a London hospital. In 1948 she married an Army colonel whom she had met in Belgium, at which point, like many other women, she left work and settled into a domestic life. ${ }^{102}$ Sister Joan Carr was not demobbed until 1948, having joined the QAs late in the war. In the immediate post-war period she was posted to Gibraltar, which she said was an interesting time. On return to Britain she worked for a short time in the theatres at her local hospital and then married in $1950 .{ }^{103}$ Morris met her husband, Malcolm, on 7 April 1945 and married him on 12 October in the same year. Her diary states, 'I know that I love him and will marry him. ${ }^{104}$ Sister Daphne Ingram left the QARANC in 1947 and married a gunner officer whom she had met in her first year in Hong Kong. ${ }^{105}$ Sister Joyce Parry Ffoulkes married in May 1943, after which both she and her new husband returned briefly to their military work before demobilisation. On the last page of her edited diary she wrote, 'Now I am facing the other way and beginning my real life.'106

Sister Betty Evans married in May 1945, but was immediately sent back to Holland with her unit. At the end of the war, she joined her husband for a while in Poona and they returned to England together in 1946, at which point Evans left nursing because she wanted a family, 'and naturally I had to be in civilian life to have a family'. ${ }^{107}$ Sister Betty Parkin's memoir recalls her new husband, Stanley's, comment upon their marriage, "Your nursing days are over, sweetheart", my husband said as we sat for the first time in our own sitting-room with the windows opened wide onto flower-filled beds.'108 Toman argues with reference to the Canadian nursing sisters that the return to domesticity was partly because professional options were so limited. As Evans' and Parkin's recollections suggest, neither the general public nor individual husbands expected wives to work after marriage. The reasons for nursing sisters not to return to hospital nursing post-marriage were therefore more complex than limited professional opportunities.

Military nurses had been awarded officer status, with its associated privileges and salary, but on demobilisation that status disappeared. ${ }^{109}$ The position of nurses was untenable. Their lives were severely curtailed by being required to live in, often in similar conditions to the student nurses under their charge and with very little money. ${ }^{110}$ Even experienced ward sisters could not afford to buy their own homes, 
nor could they necessarily provide for their old age: ${ }^{111}$ 'because they said it was a vocation, you know, it wasn't a job, so you didn't get much money, you got your keep'. ${ }^{112}$ The nursing and medical press called for married women to be able to continue to hold senior posts in the nursing profession, a move that it was argued 'might help to ventilate the cloistered atmosphere'. Such calls were not heeded. ${ }^{113}$ The ongoing and unresolved debates about living in meant that even those experienced demobbed nurses who were willing to accept the social criticism directed at women who combined work and marriage could not always find positions. In 1945 the Minister for Health argued that 'there should be no bar on the employment of married women nurses, including those who desire to live out, provided they can give the service required by the hospital. Married student nurses should also be allowed to continue their training. 114 In view of the gendered assumption that a married woman could not look after her husband and give appropriate service to her patients, is likely that matrons used the 'provided they can give the service required by the hospital' to deny them employment. Despite knowing that choosing marriage meant forgoing a professional life, women, including nurses across the country, chose marriage.

The desire to return to 'normal' family life was, according to Richard Bessel and Dirk Schumann, even more important to the nations which had been affected by the Second World War than those of the First World War. That earlier conflict may have been brutal and dehumanising, but it did not witness the destruction of whole swathes of the civilian population in the mass bombing of cities or the genocide of European Jewry. ${ }^{115}$ How could such memories be managed, or understood, how could the guilt of even knowing what happened be assuaged? ${ }^{116}$ Better to bury that knowledge. The problem for nurses and other women workers was that the normality that was sought was one based in the male hegemony of the mid-twentieth century. Normality meant women being returned to the home, childbirth and child rearing, whilst men regained a sense of self through civilian work. $^{117}$

The war had temporarily extended women's access to work outside the home, but this access was for the duration only, and was fraught with complex gendered contradictions. ${ }^{118}$ Women in Britain had been expected to be active citizens for the war effort, but to remain 
feminine. ${ }^{119}$ They were expected to 'keep the home fires burning', but their homes were bombed. They were expected to be generous to fighting men, but to be so in a way that did not contravene expected sexual and social mores. ${ }^{120}$ Nevertheless, although women had only been 'filling in the gaps' whilst the men went to war, ${ }^{121}$ across the globe many found even this contingent participation in the public world emancipating. ${ }^{122}$ The cessation of hostilities witnessed an end to the gender-bending attitudes that had been tolerated during the war and a reassertion of traditional social mores.

At war's end, demobilised women were expected to return to the home, to care for their husbands and raise their children. ${ }^{123}$ The men, however, re-established themselves in the jobs that they had 'donated' to their womenfolk whilst they had been away fighting. Propaganda to encourage the reinstatement of traditional family life was extensive. Official texts such as Rebuilding Family Life in the Post-War World quickly reasserted the regard for women who stayed at home. ${ }^{124}$ Arguments were made that there had been an increase in juvenile delinquency amongst the young because mothers had been out at work during the war. The only way to reduce delinquency was for women to return to the home. ${ }^{125} \mathrm{Dr}$ Eliot Slater, one of the contributors to the pamphlet, was even more stark: 'It needs at least two people to run a house, one to earn the money, the other to look after the house. ${ }^{126}$ Many ordinary members of the public also wished to restore pre-war social constructs that vilified all women, ${ }^{127}$ including the educated and professional, who tried to combine marriage and work. ${ }^{128}$

New domestic appliances and technologies may have been advertised as methods to free the women of Britain from the burden of domestic drudgery, but the work remained women's work. ${ }^{129}$ According to Harold Smith, surveys conducted in the latter months of the war, showed that only about 25 per cent of women who had been employed in factories during the war wanted to stay in work. Most wished to get married and have children. ${ }^{130}$ Given that factory work was monotonous and unpleasant, to identify this as a trend for all women is simplistic. Yet the expectation was so pervasive that even women's magazines heralded the return to the home and hearth as the normal and desirable space for women. ${ }^{131}$ Certainly the historiography of post-war women's lives suggests that many women were happy to return to the home after the chaos of war. ${ }^{132}$ 
The Mass Observation Unit's own assessment was that service women, having in many cases experienced true adventure, would be less likely to wish to return to domestic life. ${ }^{133}$ Nevertheless, even women who had taken on some of the most dangerous wartime work, such as those in the SOE, married quickly post-war and settled into domestic routine and traditional home lives. ${ }^{134}$ Ali Haggart's oral history study of housewives from the post-war period identifies women who were glad to return to the home and relished their time raising their children, even if their relationships with their husbands were not always a positive experience. ${ }^{135}$ In Reconstructing Women's Wartime Lives, Penny Summerfield expresses a level of surprise at the number of women who maintained they were pleased to return to a more traditional role of home and hearth, with 38 of the 42 women interviewed marrying post-war. ${ }^{136}$ Summerfield acknowledges the belief of Marxist feminists in the 1970s and early 1980s that these women were expressing a 'false consciousness' or 'collusion' in their desire to return home, ${ }^{137}$ but suggests that such an attitude towards the generation of women who returned to 'normal' civilian life after the Second World War is unnecessarily pejorative. Women wanted to marry and have a family. ${ }^{138}$ The critical issue was that, unlike the men they married, the social pressure to not work outside the home once married was significant. In the absence of contraception that enabled the women themselves to control child-birth, the birth rate rose rapidly. ${ }^{139}$ With the closing of nurseries at the end of hostilities, many women had no choice but to return to the home to care for their children. ${ }^{140}$

Although working-class women had invariably worked during their marriage out of necessity, middle-class women did not. Not working, therefore, became a social aspiration for women of the respectable working class and lower middle class. Deborah Montgomerie maintains that 'Women homemakers, actual and potential, were reverenced and praised within the wartime iconography of femininity. ${ }^{141}$ It was thus not difficult to cultivate this into a trope of arch-domesticity in the post-war era as men were demobilised and needed 'their' jobs back. The complex interplay of social expectation, economic necessity and romantic love played into this ideology and women returned to the domestic space and marriage. Nursing had long offered social mobility to women from the lower middle class 
or respectable working class. Having gained social mobility through nursing and joined the middle class, they were expected to follow its codes and leave the profession on marriage; married middle-class women did not work. ${ }^{142}$ As with previous generations, experienced nurses were therefore lost to the profession.

\section{Conclusion}

The final months of the war provided nursing sisters with some of the most challenging work of their wartime careers. Restoring the liberated inmates of Bergen-Belsen to a semblance of humanity and rehabilitating men who had been POWs of the Japanese demanded exemplary clinical skills and also methods of patient engagement that would rarely have been encountered on the wards of British hospitals pre-war. Despite the valuable professional skills that active service overseas and this war's-end work had engendered, few demobbed nurses had the chance to support the development of the profession in the post-war British hospital system. The reason for the limited acknowledgement of these new and important nursing methods in hospitals has previously been levelled at the profession itself. The demobbed nurses could not or would not re-engage with such a rigid system. The nurses' testimonies used in this book suggest a more complex depiction of post-war opportunities.

Hospitals did not encourage living out and, despite government claims that opportunities for independent living should be available, nurses' salaries were not commensurate with private home rental and the government would not provide additional allowances. Furthermore, post-graduate training opportunities for demobbed medical officers were not matched for nursing sisters, thus precluding them from developing themselves for senior positions. Finally, many nurses did not return to the profession because they wanted to marry, or had already married on active service. Some hospitals certainly made recruitment very difficult for married women, but the nation more widely wanted women to return to the home and raise families. Demobilised nursing sisters were therefore caught in the interstices of traditionalist hospital regimes with long hours, erratic off-duty and limited options for living independently and post-war conservatism that demanded that women should marry and bear children. In 
the absence of nurseries, and faced with the prospect of the double burden of home and professional work, many women, including nurses, had no choice but to return to the home and stay there.

\section{Notes}

1 The Advisory Service of the Royal College of Nursing, 'The re-settlement of nurses: Back to civilian life' (London: H. and Co., December 1945), 1.

2 Penny Starns, 'Fighting militarism? British nursing during the Second World War', in Roger Cooter, Mark Harrison and Steve Sturdy (eds), War, Medicine and Modernity (Stroud: Sutton Publishing, 1998), 197; Mary Sarnecky, A History of the US Army Nurse Corps (Philadelphia, PA: University of Pennsylvania Press, 1999), 280; Penny Starns, Nurses at War: Women on the Frontline, 1939-45 (Stroud: Sutton Publishing, 2000), 152-8; Cynthia Toman, An Officer and a Lady: Canadian Military Nursing and the Second World War (Vancouver: University of British Columbia Press, 2007), 184-7; Nicola Tyrer, Sisters in Arms: British Army Nurses Tell their Story (London: Phoenix, 2008), 303-4.

3 There were debates in the nursing press related to the need for student nurses to live in, but not those who were qualified. Nevertheless, comments such as 'sickness is much more prevalent amongst non-residents', do suggest an antipathy towards nurses living away from the hospital. V.E. Darley, 'Living out is not such an advantage', Nursing Mirror (23 March 1946): 424; Anonymous, 'Living out and living in', Nursing Mirror (2 March 1946): 361-2.

4 Sonya O. Rose, Which People's War? National Identity and Citizenship in Britain, 1939-1945 (Oxford: Oxford University Press, 2003, Kindle edition), loc. 3830 .

5 Sue Bruley, Women in Britain since 1900 (Basingstoke: Palgrave Macmillan, 1999), 118.

6 Margaret Hadley Jackson, 'Causes and significance of the dwindling family', in Sir James Marchant (ed.), Rebuilding Family Life in the Post-War World: An Enquiry with Recommendations (London: Odhams Press, 1945), 89.

7 Sarah Burke Odland, 'Unassailable motherhood, ambivalent domesticity: The construction of maternal identity in Ladies' Home Journal in 1946', Journal of Communication Inquiry 34, 1 (2010): 61-84.

8 C.M.S. Baker, 'Aftermath of war, September 1945', Imperial War Museum Private Papers (hereafter IWM) Documents 6341. It should be noted that the Queen Alexandra's Imperial Military Nursing Service did not actually change its name to the Queen Alexandra's Royal Army Nurse Corps (QARANC) until 1 February 1948. Juliet Piggott, Queen Alexandra's Royal Army Nurse Corps (London: Leo Cooper, 1975), 86. 
9 Catherine M. Butland, 'Army sisters in battledress or the chosen few or follow fate', 89, MMM QARANC/PE/1/74/BUTL Box 8. The seven months refers to her time with the No. 1 Mobile Military Hospital which she and four colleagues had rejoined the previous Christmas. Cynthia Toman identifies the dissonance that many nurses felt at the end of the war. They were, she argues, glad the war was over, but sad to return to lives that would never be as exciting again. Toman, An Officer and a Lady, 167.

10 Ann Radloff, 'Going to Gooseberry Beach: Travels and adventures of a nursing sister', 27, IWM Documents 147.

11 Radloff, 'Going to Gooseberry Beach', 30.

12 The information relating to Radloff's later life is not available in her memoir. Although the contents page identifies that these travels are considered in part 2 of the memoir, the IWM archivists are not aware of these later chapters. There is no second part to her memoir in their collection. It is not therefore known whether her travels were as a professional nurse, as a wife or in another capacity.

13 The BAOR was an employer not only of nurses, but of women more generally. The need for women to participate in post-war reconstruction overseas created work in the British zone in Germany. Although many welcomed this work as a change to the confines of their British home life, they were placed in low-level clerical jobs, where there was little autonomy or relinquishment of servitude to their male bosses. Ruth Easingwood, "I was merely a shorthand typist": British women at work in the British zone of occupied Germany, 1945-1949', Women's History Magazine 67 (2011): $20-7$.

14 Mary Morris, 'The diary of a wartime nurse' (7 June 1945), 198, IWM Documents 4850; Mary Morris, A Very Private Diary: A Nurse in Wartime, ed. Carol Acton (London: Weidenfeld and Nicolson, 2014), 171.

15 J. Elsie Gordon, 'With the BAFO and BAOR - 4: In the depressing city of Berlin', Nursing Times (8 December 1945): 158.

16 Morris, 'The diary of a wartime nurse' (21 July 1945); Morris, A Very Private Diary, 257.

17 Morris, 'The diary of a wartime nurse' (16 June 1947).

18 Morris, 'The diary of a wartime nurse' (27 July 1947); Morris, A Very Private Diary, 281.

19 Cecelia Helen Burnette Christie, oral history interview by Conrad Wood, 25 March 1993, IWM Sound Archive 13121.

20 Anonymous, oral history interview by Conrad Wood in 1998, IWM Sound Archive 18451.

21 Baker, 'Aftermath of war, September 1945', 2-3.

22 For detailed discussions on the work of nurses at Bergen-Belsen Concentration Camp, see for example, Jane Brooks, "Uninterested in anything except food": Nurse feeding work with the feeding the liberated 
inmates of Bergen-Belsen', Journal of Clinical Nursing 21 (2012): 2958-65; Jane Brooks, "'The nurse stoops down ... for me": Nursing the liberated persons at Bergen-Belsen', in Jane Brooks and Christine Hallett (eds), One Hundred Years of Nursing Wartime Practices, 1854-1953 (Manchester: Manchester University Press, 2015). There are a range of texts about the liberation of Bergen-Belsen, including the medical aspects. See especially Jo Reilly, David Cesarani, Tony Kushner and Colin Richmond (eds), Belsen in History and Memory (London: Frank Cass, 1997); Ben Flanagan and Donald Bloxham (eds), Remembering Belsen: Eyewitnesses Record the Liberation (London: Vallentine Mitchell, 2005); Ben Shephard, After Daybreak: The Liberation of Belsen, 1945 (London, Pimlico, 2005); Suzanne Bardgett and David Cesarani (eds), Belsen 1945, New Historical Perspectives (London: Vallentine Mitchell, 2006); Leslie Hardman and Cecily Goodman, The Survivors: The Story of the Belsen Remnant (London: Vallentine Mitchell, 2009); Mark Celinscak, 'At war's end: Allied forces at Bergen-Belsen' [unpublished PhD thesis] (Toronto: York University, 2012).

23 Mary Bond, Wartime Experiences from the Midnight Sun to Belsen (Cardigan: E.L. Jones and Son, 1994), 47.

24 Bond, Wartime Experiences from the Midnight Sun to Belsen, 47-8.

25 Bond, Wartime Experiences from the Midnight Sun to Belsen, 48.

26 Molly Silva Jones, 'From a diary written in Belsen' (1945), 4, IWM Documents 9550.

27 Jones, 'From a diary written in Belsen', 2.

28 Sister B.B., 'Nursing in Belsen Camp', Nursing Times (14 July 1945): 204.

29 F.M. Lipscombe, 'Medical aspects of Belsen concentration camp', The Lancet (8 September 1945): 314.

30 J.A.D. Johnston, 'Administrative report - Belsen Concentration Camp', 3 (c. June 1945), IWM Documents 10541.

31 Brooks, “'The nurse stoops down ... for me”', 226; Reilly, 'Cleaner, carer and occasional dance partner?', 156.

32 Reilly, 'Cleaner, carer and occasional dance partner?', 156

33 Mary Copeland, in Barbara Mortimer, Sisters: Extraordinary True-Life Stories from Nurses in World War Two (London: Hutchinson, 2012), 227.

34 Mary Sands, 'Notes on dealing with Belsen' (April 1993), 6, MMM Belsen Concentration Camp - 1945. For some reason, Sands calls Bergen-Belsen, 'Belsen-Bergen'; it is not known why she does, but in all the documents reviewed she is the only person to refer to it in this manner.

35 K.J. Elvidge, 'Letter to "My Darling"' (26 May 1945), IWM Documents 1029.

36 Sister Penny Salter, 'Long ago and far away: A distant memory: A diary, c. 1938-1970', 157, UK Centre for the History of Nursing (hereafter UKCHN), University of Manchester; IWM Documents 17649.

37 Salter, 'Long ago and far away', 157. 
38 Salter, 'Long ago and far away', 158.

39 Salter, 'Long ago and far away', 164.

40 Agnes Kathleen Dunbar Morgan, letter 58 (August 1943), CMF. 'Still with the lamp: letters to my mother by an army nursing sister. Egypt - North Africa - Sicily - Italy, 1941-1944', IWM Documents 16686.

41 Alan Gregg, 'Adaptation of survival: Reflections on our postwar problems', American Journal of Nursing 44, 10 (1944): 923.

42 Penny Summerfield, Reconstructing Women's Wartime Lives: Discourse and Subjectivity in Oral Histories of the Second World War (Manchester: Manchester University Press, 1998), 82.

43 Jessie Sarah Catherine Wilson, 'We also served, 1940 ...', 61, UKCHN, University of Manchester.

44 P.M. Dyer, 'When life was grey and scarlet: A recollection of life as an Army Nursing Sister', 115-16, MMM QARANC/PE/1/151/DYER Box 8.

45 The Advisory Service of the Royal College of Nursing, 'The re-settlement of nurses'.

46 Starns, Nurses at War, 138.

47 Anonymous, 'Correspondence', The British Journal of Nursing (May 1945): 54-5.

48 'Forces obtain nurses easily', Telegraph (10 December 1946), Press cuttings re: nurses, MMM QARANC/PE/1/27.

49 Vera Jones, 'My dear mother and father' (29 December 1944), A Time To Remember: A Record of Nursing Experiences, Impressions and Travels During World War II Contained in Letters Sent Home from The East (London: Athena Press, 2005), 324. It is not known if her application was successful.

50 Anonymous, 'From all quarters'.

51 Diana Wilson, 'Obituary: Dame Monica Golding', Independent (25 July 1997), http://www.independent.co.uk/news/people/obituary-dame-monicagolding-1252598.html [accessed 21 October 2016].

52 For a full and detailed discussion of Margot Turner's wartime experiences and life, see John Smyth, The Will to Live: The Story of Dame Margot Turner (London: Hills and Lacy, 1970); Penny Starns, Surviving Tenko: The Story of Margot Turner (Stroud: The History Press, 2010).

53 Women, including nurses, of all allied nations were interned by the Japanese in Hong Kong, Sumatra and Malaya during the Second World War. For a detailed discussion of the lives of those women interned in Japanese camps see Lavinia Warner and John Sandilands, Women Beyond the Wire: A Story of Prisoners of the Japanese, 1942-45 (London: Michael Joseph, 1982); Elizabeth M. Norman and Sharon Eifried, 'How did they all survive? An analysis of American nurses' experiences in Japanese Prisoner-of-War camps', Nursing History Review 3 (1995): 105-27; Bernice Archer and Kent Fedorowich, 'The women of Stanley: Internment in Hong Kong, 1942-45', Women's History Review 5, 3 (1996): 373-99; 
Penny Starns, Nurses at War: Women on the Frontline, 1939-45 (Stroud: Sutton Publishing, 2000); Christina Twomey, 'Australian nurse POWs: Gender, war and captivity', Australian Historical Studies 36, 124 (2004), 255-74; Christina Twomey, 'Double displacement: Western nurses return home from Japanese internment camps in Second World War', Gender and History, 21, 3 (2009): 670-84; Angharad Fletcher, 'Sisters behind the wire: Reappraising Australian military nursing and internment in the Pacific during World War II', Medical History 55 (2011): 419-24; Felicia Yap, 'Voices and silences of memory: Civilian internees of the Japanese in British Asia during the Second World War', Journal of British Studies 50 (2011): 917-40; Felicia Yap, 'Creativity and the body: Civilian internees in British Asia in the Second World War', in Gilly Carr and Harold Mytum (eds), Cultural Heritage and Prisoners of War: Creativity Behind Barbed Wire (London: Routledge, 2012); Jane Brooks, 'Wartime nursing: Feeding as forgotten practice', in Sandra B. Lewenson, Annemarie McAllister and Kylie Smith (eds), Nursing History for Contemporary Role Development (New York: Springer, 2017).

54 Anonymous, 'Obituaries: Brig Dame Margot Turner', MMM QARANC/ RQ/2/3/2/HOVE, box 97.

55 The evidence for post-war service in the TANS by some Second World War Reservists is limited. There are no known diaries or memoirs, but medals in the medal drawers at the MMM, identify that Sister M.V.D. Hyland, Miss S.S. Epps and Cecily Earp all joined the TANS after the war ended.

56 E.R. Schofield, 'Benghazi', in Queen Alexandra's Royal Army Nursing Corps Association, The Gazette 3, 5 (1958): 6.

57 Anonymous, 'Eulogy: Sally Hepworth (nee Sarah Dixon)', MMM QARANC/PE/1/432/HEPW.

58 Marjorie Patricia Hunt, oral history by Conrad Wood, 10 August 1996, IWM Sound Archive 16803.

59 Katharine H. Jones, 'Miss Jane Amelia Patterson, C.B.E., R.R.C. (late Chief Principal Matron, India, QAIMNS, 1922-1947)', Queen Alexandra's Royal Army Nursing Corps Association, The Gazette 3, 6 (1958): 11.

60 Susan McGann, Anne Crowther and Rona Dougall, A History of the Royal College of Nursing A Voice for Nursing, 1916-90 (Manchester: Manchester University Press, 2009), 128.

61 It is not the intention in this chapter to provide a detailed discussion on the foundation of the NHS; there is a wealth of literature on this topic. For a full and detailed account see, for example, Charles Webster, The National Health Service: A Political History (Oxford: Oxford University Press, 2002). For the history of nursing and the NHS see, for example, Monica E. Baly, Nursing and Social Change (London: Routledge, 1995); See also the special issue of the International History of Nursing Journal, 'Fifty years of nursing in the NHS', International History of Nursing Journal 3, 3 (1998). 
62 Catherine Arnold Hutchinson, 'My war and welcome to it' (2001), 225. IWM Documents 11950.

63 Hutchinson, 'My war and welcome to it', 226. It appears from Hutchinson's memoir that the regime at East Grinstead was not the norm. She clearly identifies that she married and had two daughters, yet she was able to continue to work at the hospital. Hutchinson, 'My war and welcome to it', 227.

64 Anonymous, 'Covering commentary: The Second World War diaries of Miss Esther Helen Audrey Luker, ARRC', IWM Documents 1274.

65 Starns, Nurses at War.

66 Mortimer, Sisters, 294.

67 Julie Fairman and Joan E. Lynaugh, Critical Care Nursing: A History (Philadelphia, PA: University of Pennsylvania Press, 1998), 11.

68 Starns, Nurses at War, 138.

69 Starns, Nurses at War, 138.

70 Tyrer, Sisters in Arms, 303.

71 Jones, 'My dear mother and father' (30 September 1944), A Time To Remember, 299.

72 Bruley, Women in Britain since 1900, 125.

73 See, for example, Anonymous, 'Higher pay for nurses', The Lancet (29 December 1945): 859; Anonymous, 'New Rushcliffe Committee scales for many nursing posts', The British Journal of Nursing (August 1946): 90.

74 Starns, Nurses at War, 30. The Nurses' Salaries Committee, chaired by Lord Rushcliffe, was established in 1941 to consider nurse' salaries and conditions of work. See also McGann et al., A History of the Royal College of Nursing, 110-11.

75 Butland, 'Army sisters in battledress', 131. There is no information related to Butland's post-war life.

76 Anonymous, 'Editorial: For the good of all', Nursing Times (19 January 1946): 42.

77 Butland, 'Army sisters in battledress', 137.

78 McGann et al, A History of the Royal College of Nursing, 129.

79 Charles Webster, 'Nursing as the early crisis of the NHS', International History of Nursing Journal 3, 3 (1998): 38.

80 Anonymous, 'The grave shortage of nurses', The British Journal of Nursing (December 1948): 144. Nor was the problem limited to British hospitals. Sharon Richardson argues that in Canada, the shortage of recruits to hospital training programmes in the post-war era was exacerbated by the refusal of many young women to train under the harsh and hierarchical system of nurse apprenticeships. Sharon L. Richardson, "Stand up and be counted": Nursing at the Calgary General Hospital after the Second World War', Canadian Bulletin of Medical History 18 (2001): 297-323.

81 Gladys B. Carter and Evelyn C. Pearce, 'The scarcity of nurses. Working conditions, domestic duties and training', The Times (16 May 1945), MMM 
QARANC/CF/4/5/1/VARI Box 18. Gladys Carter, author of the 1939 monograph A New Deal for Nurses, published by Victor Gollancz, was a nurse and economist and later a member of academic staff at the Nursing Studies Unit at the University of Edinburgh. Evelyn Pearce was the senior tutor at the Middlesex Hospital School of Nursing and author of the highly influential book A General Textbook of Nursing, first published in 1938, which ran for at least 19 editions.

82 Gladys B. Carter, 'Reconsideration of nursing: Its fundamentals, purposes and place in the community. 3. Recruitment and training of nurses', Nursing Mirror (1946): 316-18.

83 Dame Katharine Jones, 'Q.A.I.M.N.S. professional and military status', Nursing Times (27 January 1945): 60.

84 McGann et al., A History of the Royal College of Nursing,135.

85 Candidus, 'The lady with the lamp is now the lady with the hump', The Daily Sketch (24 August 1944), MMM QARANC/CF/4/5/1/VARI Box 18.

86 For example, appointments pages in the Nursing Times for 7 April 1945. Several hospitals advertise for ward sisters, sister tutors and all state 'residential'. County Hospital, Dartford advertised for an assistant sister tutor: 'Salary according to service within the appropriate Rushcliffe Scale $£ 200$ to $£ 250$ a year with full residential emoluments.' Kent County Council, County Hospital, Dartford Training School for Nurses, 'Applications are invited', Nursing Times (7 April 1945): supplement iii; County Hospital Keighley, advertised for 'Ward sister ... Salary $£ 130 / £ 200$ per annum together with full residential emoluments valued at $£ 100$ per annum', County Council of the West Riding of Yorkshire, County Hospital Keighley, 'Applications are invited', Nursing Times (7 April 1945): supplement iii; Infectious Diseases Hospital, Burnley advertised for an assistant matron, 'Rushcliffe salary, $£ 325$ to $£ 370$ per annum, less $£ 120$ value of annual emoluments', Infectious Diseases Hospital, Burnley, 'Applications are invited', Nursing Times (14 July 1945): supplement viii.

87 Anonymous, 'Editorial: The ward sister and professional organization', Nursing Times (11 August 1945): 513.

88 J. de Pinto, 'A new plan for hospital staffs', Nursing Times (1 December 1945): 801.

89 Anonymous, 'Editorial: Coming home - Army nurses think of demobilisation', Nursing Times (16 February 1946): 127.

90 Anonymous, 'Editorial: Nursing goes forward', Nursing Times (17 November 1945): 751. Italics in the original.

91 Anonymous, 'Editorial: For the good of all', 41-2.

92 Starns, Nurses at War, 150.

93 Karen Flynn, 'Proletarianization, professionalization and Caribbean immigrant nurses', Canadian Woman Studies 18, 1 (1998): 57-60; Julia Hallam, Nursing the Image: Media, Culture and Professional Identity (London: 
Routledge, 2000), 121; M. Shkimba and Karen Flynn, "'In England we did nursing": Caribbean and British nurses in Great Britain and Canada, 1950-70', in Barbara Mortimer and Susan McGann (eds), New Directions in Nursing History: International Perspectives (London: Routledge, 2004); Diana Solano and Anne Marie Rafferty, 'Can lessons be learned from history? The origins of the British imperial nurse labour market: A discussion paper', International Journal of Nursing Studies 44, 6 (2007): 1055-63; McGann et al., A History of the Royal College of Nursing, 273-4.

94 According to Mary Sarnecky, cadet schemes in the USA were the cause of some ex-Army nurses leaving hospital nursing completely. Sarnecky, $A$ History of the US Army Nurse Corps, 280.

95 Starns, Nurses at War, 153-4.

96 Penny Starns identifies the irony that the General Nursing Council wanted compulsory entry requirements re-introduced, and yet did not want educational reform for those candidates once they had joined the profession. Starns, Nurses at War, 140.

97 Hallam, Nursing the Image, 95.

98 David Proctor, T348, RAMC orderly and later RGN, and Arthur Brompton, T360, RAMC medic in Egypt, both RCN Oral History Archive, Edinburgh; Mortimer, Sisters, 299. For a useful discussion of the movement of men into nursing and the differences in how they were treated by the hospitals that employed them, see Graham J. Thurgood, 'Nurses' voices from the archives', Journal of the Society of Archivists 31, 2 (2010): 142.

99 McGann et al., A History of the Royal College of Nursing, 152.

100 One key change in the marriage rates post-war was the increase in those under 21 years of age marrying. Braybon and Summerfield suggest that whereas in 1938 one in six of all women marrying were under 21 years old, in 1945 this had increased to one in four. Gail Braybon and Penny Summerfield, Out of the Cage: Women's Experiences in Two World Wars (London: Pandora, 1987), 267. For a discussion on the discourse of postwar stability, see Summerfield, Reconstructing Women's Wartime Lives, 257-9.

101 Helen M. Sweet and Rona Dougall, Community Nursing and Primary Healthcare in Twentieth-Century Britain (New York: Routledge, 2008), 82.

102 I am indebted to Cyril Fish for helping with the oral history from Florence Hardy. Mrs Hardy was not able to talk herself, so Mr Fish kindly acted as an intermediary. The brief interview was taken via telephone with Mr Fish on 5 December 2013.

103 Joan Carr, oral history interview by Jane Brooks at her home in the North West, 22 November 2013, UKCHN, University of Manchester.

104 Morris, 'The diary of a wartime nurse' (23 April 1945); Morris, A Very Private Diary 157.

105 Ingram, 'Experiences of an Army Nurse', 10. 
106 Joyce Ffoulkes Parry, Joyce's War: The Second World War Journal of a Queen Alexandra's Imperial Military Nursing Service Nurse, ed. Rhiannon Evans (Stroud: The History Press, 2015, Kindle edition), loc. 3604.

107 Betty Evans, oral history interview via telephone by Jane Brooks, 10 January 2014, UKCHN, University of Manchester.

108 Betty C. Parkin, Desert Nurse: A World War II Memoir (London: Robert Hale, 1990), 170.

109 Starns, Nurses at War, 138.

110 Elsie Davies, oral history interview by Jane Brooks at her home in Manchester, 18 December 2012, UKCHN, University of Manchester. Davies had not been a military nurse during the war, but having trained in Manchester from 1942 experienced war nursing as a civilian nurse. Her observations on civilian sisters are therefore particularly poignant.

111 Eileen Richardson, 'Memories of nursing', Bulletin of the UK Association for the History of Nursing 5 (2026): 70-2. Richardson's oral history study is based on the lives of a number of nurses who retired to the Retired Nurses' Home in Bournemouth, on the south coast of England. The home was established in the 1930s for nurses who, 'when their working time was over were unable either to find or afford accommodation for their Retirement'. Richardson, 'Memories of nursing', 70. This problem was not confined to British nurses. Lily Mary David wrote of US nurses that, 'Lack of retirement pensions and security against unemployment is the most frequent source of dissatisfaction in nursing. Rates of pay and opportunities of promotion and pay increases are also leading causes of dissatisfaction.' The most frequent reason for leaving nursing were because of marriage, but again, it is not known if fewer nurses would have left the profession for marriage if a more secure future could have been promised, or would have chosen to stay in nursing on marriage if that had been an option. Lily Mary David, 'The economic status of the nursing profession: A preliminary report of the socio-economic study, undertaken to reveal how nurses compare in their working and living conditions of women in other professions', The American Journal of Nursing 47, 7 (1947): 456.

112 Davies, oral history, 18 December 2012.

113 Anonymous, 'The nurse in charge', The Lancet (4 December 1943): 705.

114 Minister of Health, Secretary of State for Scotland and the Minister of Labour and National Service, 'Staffing the hospitals: An urgent national need', International History of Nursing Journal 3, 3 (1998): 15. Reprinted from pamphlet, Minister of Health, Secretary of State for Scotland and the Minister of Labour and National Service, 'Staffing the hospitals: An urgent national need' (London: HMSO, 1945) RCN Archives, Pamphlet Collection $11 \mathrm{AD}, \mathrm{RCN}$ Archives, Edinburgh.

115 Richard Bessel and Dirk Schumann, 'Introduction: Violence, normality, and the construction of postwar Europe', in Richard Bessel and Dirk Schumann 
(eds), Life after Death: Approaches to a Cultural and Social History of Europe during the 1940s and 1950s (Cambridge: Cambridge University Press, 2003).

116 In her diary of her work during the liberation of Bergen-Belsen, Sister Molly Silva Jones described her 'shame - remorse, yes, because even in 1934 we had heard of these camps and not realised, not wanted to realise that such things could happen'. Molly Silva Jones, 'From a Diary Written in Belsen', 2, IWM PP 99/86/1. See also Brooks, 'The nurse stoops down ... for me', 214.

117 For a detailed discussion of marriage, sex and child rearing in post-war Britain, see especially Pat Thane, "Family life and "normality" in postwar British culture', in Richard Bessel and Dirk Schumann (eds), Life after Death: Approaches to a Cultural and Social History of Europe during the 1940s and 1950s (Cambridge: Cambridge University Press, 2003).

118 Penny Summerfield and Corinna Peniston-Bird, "Women in the firingline": The Home Guard and the defence of gender boundaries in Britain in the Second World War', Women's History Review 9, 2 (2000): 232.

119 Cynthia Enloe, Does Khaki Become You? The Militarization of Women's Lives (London: Pandora, 1988), 185; Summerfield, Reconstructing Women's Wartime Lives, 78. Summerfield pursues the narrative that women are in a no-win situation, in which they will always be expected to be two completely contradictory selves. As such, typically, they are criticised for working and not having children, and working and having children. During war this is exemplified as they are expected to work in 'men's jobs' to support the war, but not be masculine in that work and run the home too. In doing so they are unable to earn the same wage as men, their work is 'diluted', they cannot do the men's work in the same way as men, because of injunctions to be feminine and continue with domestic duties. Summerfield, Reconstructing Women's Wartime Lives.

120 John Costello, Love, Sex and War: Changing Values 1939-45 (London: Collins, 1985); Enloe, Does Khaki Become You?, particularly 29-31; Rose, Which People's War?

121 Lucy Noakes, War and the British: Gender, Memory and National Identity (London: I.B. Tauris, 1998), 71.

122 Leisa D. Meyer, Creating GI Jane: Sexuality and Power in the Women's Army Corps During World War II (New York: Columbia University Press, 1996), 181.

123 This process of domesticity pervaded not only British culture. In her study of members of the Women's Army Corps, Leisa Meyer describes how one of her participants, 'was caught up in the cultural desire for normalcy and made the choice to marry shortly after discharge'. Meyer, Creating GI Jane, 182.

124 Arthur Salusbury MacNalty, 'Influence of war on family life', in Sir James Marchant (ed.), Rebuilding Family Life in the Post-War World: An Enquiry with Recommendations (London: Odhams Press, 1945), 133. 
125 MacNalty, 'Influence of war on family life', 134.

126 Eliot Slater, 'Psychological aspects of family life', in Sir James Marchant (ed.), Rebuilding Family Life in the Post-War World: An Enquiry with Recommendations (London: Odhams Press, 1945), 100.

127 Bruley, Women in Britain, 125.

128 There is a significant body of literature on the position of educated professional women and students in the post-war period, all of which points to a narrowing of spheres and closing of doors. However, the picture is more complex and the return to pre-war certainties was not absolute. Carol Dyhouse argues that medical schools imposed 'quotas' on women, but they could not exclude them completely. Carol Dyhouse, 'Women students and the London medical schools, 1914-39: The anatomy of a masculine culture', Gender and History 10, 1 (1998): 111. Cambridge University reinstated 'quotas' for women students more generally, but from 1948 'conceded degrees' to them. Carol Dyhouse, 'Troubled identities: Gender and status in the history of the mixed college in English universities since 1945', Women's History Review 12, 2 (2006): 172. Girton remained an option for 'clever women', but the career choices for them on graduation were limited and about one third entered teaching. Pat Thane, 'Girton graduates: Earning and learning, 1920s-1980s', Women's History Review 13, 3 (2004): 354.

129 Rose, Which People's War?, loc. 3814.

130 Harold Smith, 'The effect of the war on the status of women', in Harold Smith (ed.), War and Social Change: British Society in the Second World War (Manchester: Manchester University Press, 1986), 216.

131 Noakes, War and the British, 72. See also Costello, Love, Sex and War, 370. Costello does present a more positive picture of the immediate post-war lives of young women, imagining a more permissive and open society than perhaps existed.

132 Lucy Noakes, “"Gentle in manner, resolute in deed”: Women and the British army in the post-war years', Women's History Magazine 76 (Autumn 2014): 5; Easingwood, 'I was merely a shorthand typist'.

133 Summerfield, Reconstructing Women's Wartime Lives, 258.

134 Juliette Pattinson, Behind Enemy Lines: Gender, Passing and the Special Operations Executive in the Second World War (Manchester: Manchester University Press, 2007), 187.

135 Ali Haggart, "Desperate housewives" and the domestic environment in post-war Britain: Individual perspectives', Oral History 37, 1 (2009): 53-60.

136 Summerfield, Reconstructing Women's Wartime Lives, 277.

137 Penny Summerfield, “They didn't want women back in that job”: The Second World War and the construction of gendered work histories', Labour History Review 63, 1 (1998): 84.

138 Maureen Honey, Creating Rosie the Riveter: Class, Gender, and Propaganda 
during World War II (Amherst, MA: University of Massachusetts Press, 1984), 6.

139 The birth rate for the September quarters of the years 1941-45 was recorded as 15.7 per 1,000. In 1946 this had risen to 19.7. The rate for the September quarter of 1947 was 22 per 1,000. Figures cited from the Registrar-General's Quarterly Return of Births, Deaths and Marriages for the September Quarter (London: HMSO, 1947), cited in Anonymous, 'Central Midwives Board. The pupil's case book', The Midwife: The British Journal of Nursing (February 1948): 24.

140 Gail Braybon and Penny Summerfield suggest that the Treasury halved its subsidy to nurseries in 1945. Braybon and Summerfield, Out of the Cage, 263.

141 Deborah Montgomerie, 'Assessing Rosie: World War II, New Zealand women and the iconography of femininity', Gender and History 8, 1 (1996): 127.

142 Krista Cowman and Louise A. Jackson, 'Middle-class women and professional identity', Women's History Review 14, 2 (2005): 171. 